\title{
THE EFFECT OF TELFAIRA OCCIDENTALIS (FLUTED PUMPKIN) EXTRACT ON THE PHOTOSTRESS RECOVERY TIME (PSRT) OF YOUNG NIGERIAN ADULTS
}

\author{
BY \\ *TIMOTHY, C. O. AND ODIMEGWU, M. I. \\ DEPARTMENT OF OPTOMETRY, ABIA STATE UNIVERSITY, \\ UTURU, ABIA STATE, NIGERIA \\ Email:drchristim@yahoo.com \\ *Corresponding author
}

\begin{abstract}
Telfaira Occidentalis (fluted pumpkin) is a vital source of plant vitamin, Zinc and a food antioxidant. The study was designed to determine the effect of Telfaira Occidentalis (T. Occidentalis) extract on the photo-stress recovery time (PSRT) of young Nigerian adults. The PSRT of forty subjects was determined before and after the ingestion of $180 \mathrm{ml}$ of the extract in three divide doses of $60 \mathrm{ml}$ daily for three days, using photic radiation from an ophthalmoscope on subjects who has a minimum PSRT of 30 seconds (secs). The post-test was measured at $24 \mathrm{hrs}$ interval for a period of $72 \mathrm{hrs}$ (3days). The results showed reduction in the mean baseline PRST value (48.56secs). The induced values were $45.30 \mathrm{secs}, 40.67 \mathrm{secs}$, and $35.38 \mathrm{secs}$ at $24 \mathrm{hrs}, 48 \mathrm{hrs}$ and $72 \mathrm{hrs}$ respectively. This showed a percentage reduction of $6.49 \%$, $16.25 \%$ and $26.73 \%$ per $24 \mathrm{hrs}$ interval. The effect was found to be insignificant $(\mathrm{P}<0.05)$. Individuals with pigment epithelial retinopathy and other retinal or macular problems could benefit from high dose of $\mathrm{T}$. Occidentalis extract administration.
\end{abstract}

KEYWORD: Telfaira Occidentails, Beta-carotene, Anti-oxidant, Photo-stress recovery time, Retinal degeneration.

\section{INTRODUCTION}

Telfaira Occidentalis is a leafy vegetable crop, which is indigenous in West Africa rainforest and East Africa. It is known and called by different names in Nigeria, the Ibo's call it ñUguò and the Yoruba's call it ñUgwuò. Vegetables have been shown to provide not only nutritional benefit but also medical benefit and contribute significantly to the improvement of human health in terms of disease prevention and therapy ${ }^{2}$.

The nutritional content of $\mathrm{T}$. Occidentalis leaves include Naicin (6.6mg), vitamin E (5.5mg), calcium $(12.0 \mathrm{mg})$, iron $(10.0 \mathrm{mg})$, vitamin A $(3.5 \mathrm{mg})$ and nicotinamide $(0.5 \mathrm{mg})^{3}$. Most of these constituents are well known haematological factors and have direct influence on production of blood from the bone marrow ${ }^{4}$.

Recent study by Olorunshola et $\mathrm{al}^{4}$ reported that T. Occidentalis has a definite and significant haematological function which is better than the effect of fesolate and folic acid used for the treatment of hemorrhage. The aqueous extract of $\mathrm{T}$ Occidentalis is more effective than the ethanolic extract and this is attributed to the higher antioxidant activity of the aqueous extract than the ethanol extract of T. Occidentalis leaves ${ }^{5}$.

The reduction is visibility by glare is an everyday phenomenon and can be defined as sensation produced by light, invading the eyes as to inhibit vision ${ }^{6}$. The intensity of the light may be great enough to cause ocular discomfort. According to Elliot et $\mathrm{al}^{6}$, they are only a minor annoyance to most people who can quickly compensate, but they can be disabling for those with certain eye conditions conversely individual with red monochromacy or cone dystrophies may experience substantial impaired vision at high intensities.

The long lasting after images (longer than $15 \mathrm{secs}$ ) produced by bright light flashes (less than about 10secs) are due to photo chemical changes in the receptors. Collins and Brown ${ }^{8}$ reported that several possible causes of prolonged light adaptation or recovery time include, the retinal pigment epithelium (RPE), which ingest destroyed membrane shed by receptor cell as well as storing and transporting vitamin A. Hence, any interference between the RPE-receptor complex such as aged related macular degeneration, chorioderemia, serous retinal detachment and pigment epithelium retinopathy disturbs these processes and slow the regeneration of photo pigment.

Also the receptors' high metabolic activity depends on the integrity of the underlying choriocapillaries. The aim of this study is to ascertain if T. Occidentalis (fluted pumkin) has any effect on photostress recovery time (PRST). 


\section{MATERIALS AND METHODS}

Forty healthy young volunteers (mean age 23.26 \pm 2.6 years) were selected irrespective of gender, refractive error, and occupation from Abia State University, Uturu. After informed consent was sought and obtained from each of them, the pre-test and post-test experiment design used in this study.

These subjects were selected after a thorough case history; external examination and funduscopy were carried out to ensure good ocular and systemic health. Subjects with ocular pathologies were not included in the study. Only subjects with a minimum PSRT of 30 seconds and VA of $6 / 6$ were selected for the study. The above criteria were necessary since the presence of any of these conditions might affect the visual parameters being tested thereby invalidating the test result.

Fresh leaves of T. Occidentalis were purchased from a local market in Uturu community of Abia State and authenticated by a botanist from the above mentioned institution. The T. Occidentalis extract used was obtained under standard hygienic condition and fresh extract was prepared on daily basis to prevent degradation and contamination.

Hundred grammes of $T$. Occidentalis was shredded and blended with mortar and pestle. Five (5) litres of Swam® water used to dilute the $100 \mathrm{~g}$ of blended T. Occidentalis and sieved with Whatman No.1-filter paper.

Photic radiation from a direct ophthalmoscope was used to produce the photic stimulus required for the test. After the initial measurement of the subjects respective PSRT, $60 \mathrm{ml}$ of the extract was administered to each subject three (3) times a day for a period of 3 days $(72 \mathrm{hrs}$ ). The use of $180 \mathrm{ml}$ per day was informed from traditional practices. The PSRT as described by Margrain and Thompson ${ }^{9}$ was reassessed three consecutive times at $30 \mathrm{mins}$ interval post ingestion of T. Occidentalis extract; the average was recorded daily for 3days (72hrs). In this way, subjects acted as their own control. The paired t-test at 0.05 level of significant was used to test significant effect due to intake of $\mathrm{T}$. Occidentalis extract.

\section{RESULTS}

The photo stress recovery time mean baseline value for the forty subjects was (48.56secs) reduced to $45.40 \mathrm{secs}, 40.67 \mathrm{secs}$ and $35.58 \mathrm{secs}$ at Day 1, Day2 and Day3 intervals respectively. These represent mean percentage reductions of $6.49 \%, 16.25 \%$ and $26.73 \%$ respectively (table 1 ).

Table 2 shows that the induced effects decreased from day 1 to day 3 for all age group. The statistical analysis however showed the t-tabulated values to be higher than the t-calculated $\left(\mathrm{T}_{\text {tab9.264 }}>\right.$ $\left.\mathrm{T}_{\text {cal0 }} 924 ; 1.186,1.986\right)$ for the respective time interval at 0.05 level of significance.

\section{DISCUSSION}

The results showed that Telfaira Occidentalis extract produced a decrease in PSRT of young adults after the administration of $180 \mathrm{ml}$ of the extract to the subject.

The mean values obtained (table1) which was measured at daily intervals for a period of 3days were lower than the mean baseline value. The greatest decrease was however observed on the $3^{\text {rd }}$ day (Table2) of administration of the extract.

The observed effect of the T. Occidentalis on PSRT can be attributed to the fact that the extract is very rich in iron, vitamin A, folic acid, zinc and protein which are active ingredients required for blood formulation (erythropoiesis) ${ }^{10}$. These compounds are variable anti-oxidants and protect against oxidative damage and help to reduce risk of degenerative diseases.

Since the study was carried out on subjects with a PSRT of more than 30seconds and was subsequently reduced by ingestion of $\mathrm{T}$. Occidentalis extract (table1), it means therefore that the various composition of the extract enhanced the activities of the RPE of the subjects. This is in conformity with the findings of $\mathrm{Oboh}^{5}$ who reported that $\mathrm{T}$. Occidentalis is a valuable antioxidant protect against oxidative damage in the body.

Hecht ${ }^{11}$ holds that there is a similarity between cone and rod vision in that the former possesses a light sensitive substance, iodopsin which behaves like rhodopsin in respect to vitamin $\mathrm{A}$. The carotene in the extract was transformed into vitamin $\mathrm{A}$, which enhanced the vision of the subjects, thereby gradually increasing retinal sensitivity on the third day of intake.

The highest decrease in PSRT within 3days of administration of the extract also shows that zinc, which is a main constituent of T. Occidentalsi, is necessary for vitamin A metabolism and retinal function and protects against photo-oxidant damages.

It is therefore suggested that individuals with pigment epithelial retinopathy and other retinal and macular problem would benefit from the administration of T. Occidentalis extract. Though the cumulative effect of T. Occidentalis on the third day was statistically insignificant, it is believed that with higher concentration/dose, significant effect will be obtained. 
TABLE 1: MEAN PSRT VALUES OF PRE AND POST T.OCCIDENTALIS EXTRACT

\begin{tabular}{|c|c|c|c|c|c|}
\hline \multirow[t]{2}{*}{ Age group } & \multirow[t]{2}{*}{ No. } & \multirow{2}{*}{$\begin{array}{l}\text { Mean baseline } \\
\text { value (secs) }\end{array}$} & \multicolumn{3}{|c|}{ Induced values (secs) } \\
\hline & & & Day 1 & Day 2 & Day 3 \\
\hline $18-22$ & 21 & 55.82 & 50.43 & 45.75 & 41.76 \\
\hline $22-26$ & 11 & 42.51 & 39.80 & 36.47 & 31.73 \\
\hline $26-30$ & 8 & 47.34 & 45.98 & 39.80 & 33.25 \\
\hline Total & 40 & 145.67 & 136.21 & 122.02 & 106.74 \\
\hline Mean & - & 48.56 & 45.40 & 40.67 & 35.58 \\
\hline$\%$ mean reduction & - & - & $6.49 \%$ & $16.25 \%$ & $26.73 \%$ \\
\hline
\end{tabular}

TABLE 2: $\quad$ MEAN INDUCED EFFECT ON PSRT DUE TO T. OCCIDENTALIS ADMINISTRATION

\begin{tabular}{|l|l|l|l|}
\hline Age & Day 1(secs) & Day 2 (secs) & Day 3 (secs) \\
\hline $18-22$ & 5.39 & 10.07 & 14.06 \\
\hline $22-26$ & 2.71 & 6.04 & 10.78 \\
\hline $26-30$ & 1.36 & 7.54 & 14.05 \\
\hline Total & 9.46 & 23.65 & 38.93 \\
\hline Mean & 3.15 & 7.89 & 12.98 \\
\hline
\end{tabular}

\section{R E F E R E N C E S}

1. Okoli, E. C., Nmorka, O. O. and Unegbu (1988): Blanching and storage of some Nigerian vegetables. Int. J. Food Sci. Tech, 23:639-41.

2. Breazile, J. E. (1971): Textbook of Veterinary Physiology. $1^{\text {st }}$ Edn. Fab and Fabiger Press, Philadelphia, pp205-10.

3. Nwufo, M. I. (1994): Effect of water stress on the post harvest quality of two leafy vegetables - T. Occidentalis and Pterocarpus sauyaxil during storage. J. Sci. Food and Agric, 64:2657.

4. Olorunshola, K. V. and Tajong, V. (2005): Comparative study of the effect of Telfaira Occidentalis ferrous sulphate and folic acid on the haematological indices in Albino rat. Nig. J. Physiol, 36:1-2.

5. Oboh, G. (2005): Nutritional and safety evaluation of some tropical green leafy vegetables. J. Food Tech, 3:389-92.
6. Elliot, D. B., Gilchrist J. and Whitaker, D. (1989): Contrast sensitivity and glare sensitivity changed with three types of cataract morphology. J. Ophthalmol. Physiol Opt, 9:2530.

7. Brindley, G. A. (1959): The discrimination of after image. Am. J. Physiol, 147:104.

8. Collins, M. and Brown, B. (1989): Glare recovery and eye relaxed maculopathy. Chin. Vis. Sci, 4:145-54.

9. Margrain T. H. and Thompson, D. (2002): Sources of variability in the clinical photostress test. Ophthalmic Physiol. Opt, 22(1):61-7.

10. Cheesbrough, M. (2002): District laboratory practice in tropical country part 2 . Low price edn. Cambridge University Press. Cambridge, pp267-347.

11. Hecht, S. (1937): Rods, cones and the chemical basis of vision. Physiol. Rev, 17(2):239-90. 